\title{
The Application of Open Building Principles in Popular Residential Buildings in Iran
}

\author{
Mohaddeseh Khosravi, "Leila Mirsaeedie and Ali Emami
}

\begin{abstract}
Published online: 30 August 2019
To cite this article: Mohaddeseh Khosravi, Leila Mirsaeedie and Ali Emami (2019). The application of open building principles in popular residential buildings in Iran. Journal of Construction in Developing Countries, 24(1): 125-140. https://doi.org/10.21315/ jcdc2019.24.1.7.
\end{abstract}

To link to this article: https://doi.org/10.21315/jcdc2019.24.1.7

\begin{abstract}
Recently large numbers of housing units have been built in Iran; however, the lack of compliance with the changing needs of different users is regarded as the main problem. The "open building" approach allows the units to be tailored to the needs and lifestyles of the users, which are flexible and adaptable. The present study aimed to investigate the possibility of using the open building approach in popular residential complexes in Gonad-e-Kavoos in north of Iran. In this study, by using the descriptive method, 40 popular residential plans were evaluated by inviting 20 designers and developers based on semi-structured interviews were examined. Based on the results, in the field of structures and facilities, there are a few limitations on the application of open building, but there are many problems related to the open unit internal separators during the process of designing and implementation. In this regard, some suggestions were recommended for these separators based on the current situation. Further, there are many capabilities and limitations in the popular designs by which design suggestions were suggested such as location and suitable proximity to fixed and open building spaces, optimal design and spatial organisation, which makes it possible to benefit from open buildings by using these items by designers.
\end{abstract}

Keywords: Open building, Mass construction, Design and building, Residential building, Iran

\section{INTRODUCTION}

\section{Statement of Problem}

Traditional housing was designed and implemented in such a way that it can adapt to the changing needs of residents and the architect and the beneficiary had a common language in the past in Iran. In traditional Iranian homes, spaces were multifunctional and their names were not determined based on the space usage. The spaces of these houses were very flexible. However, in the last century, it was necessary to build many residential complexes with increasing demand for housing, which in most cases, it was not possible to know the future residents. Contemporary housing, in most cases, is unable to meet the needs of different families as well as the changing needs of a family, unlike traditional homes. This issue, along with the high economic importance of housing as a capital asset, has caused many problems for Iranian families like social and economic problems leading to the family movement in some circumstances. Therefore, using the methods for increasing flexibility such as "open building" approach will have many benefits for residents 
and the community, and can increase social sustainability, reduce economic and social costs and constantly shift housing, increase the ownership and identity of the residential spaces.

The study area is the Gonbad-e-Kavoos city located in Golestan province in north of Iran and its popular residential buildings are similar to many urban areas in Iran. In this area, the ethnic diversity and lifestyle, migration from villages to cities, the formation of colonial regions around cities and adjacent villages, the formation of small towns which were previously villages, the transformation of rural housing and rural imagery, the existence of large families with regard to culture and traditions, making a lot of changes in housing, fluctuations in the housing market, the diversity of demand and customer demands are regarded as some characteristics of the current situation which can justify the use of open building. The present study aimed to evaluate the possibility of using open building approach based on the contexts and adapting their related properties. Finally, suggestions are presented in the areas of design and construction in this regard.

\section{OPEN BUILDING APPROACH}

"The open building theory was first presented by Nicholas John Habraken, as a Dutch architect, in which the building is divided into supports and infill. The supports usually include skeleton and installation channels while infill or movable elements usually encompass the walls of the internal separator which are available to the house residents" (Mirmoghtadaei, Talebi and Ershad, 2007).

In another definition, the open building is the proposition of an architect who can detect a variable from a permanent one (Setien, 2015). Habraken, in his book Diversity in Housing, mentioned three following key issues in housing as a design problem in the 21 st century (Habraken, 1987):

1. The house should be diverse.

2. The house should adopt changes.

3. The house should contribute to the decision making process for the user.

A lot of research has been conducted about open building approach and many residential complexes have been built around based on this approach (refer Table 1). Adopting the principles related to open building in mass housing design is not regarded as new phenomenon. Habraken suggested this approach to mass housing design by categorising the built environment into a number of levels. Based on the hierarchical levels, any given or fixed elements are called "support" and any element the user/designer is free to add in or change is known as "infill" (Kendall, 1987; Wong, 2010).

Recently, a large number of projects have been conducted based on residential open buildings, which are expanding worldwide. In some European countries, real estate companies have started developing open building projects, due to local government incentives and competitions, as well as satisfying the market. Among these countries, we can refer to Finland, Switzerland, the Netherlands (Kendall, 2015a) and Russia (Kendall and Kiseleva, 2013).

Regarding the use of open buildings in Asia, Japan and Korea are regarded as the pioneers for constructing open building projects called "Skeleton/Infill in Japan". Some pioneering architects like Yositika Utida at Tokyo University and Professor Kazuo Tatsumi at Kyoto University in Japan directed some architects and 
researchers working in private offices, universities and government agencies to play a significant role in constructing open building in Japan. In 1994, the next NEXT 21 project funded by Osaka Gas started to build open building, new energy systems, as well as building technology (Kendall, 2015a).

Like Japan, the use of open building is very popular in South Korea although they implemented more simple construction systems. According to Mirmoghtadaei et al. (2007), a large number of residential complexes have been constructed by adopting this approach by public sector. Some pioneering architects and academics have developed open building in China since 1980. Recently, the China Institute of Building Standard Design and Research has initiated cooperating with local developers and product manufacturers in order to promote open building. In this regard, as Kendall (2015a) emphasised, a large number of "skeleton/infill" projects have been built in Beijing and Shanghai by considering Japanese experiences in some cases while some were planned by Chinese architects.

Nowadays, some developing countries have focused on developing the principles related to open building. The documents for ground breaking documentation related to additional housing processes has been performed in Mexico, India, South Africa and some other places. In addition, some pioneering projects have been conducted in Mexico and Chile (Kendall, 2015a).

Mirmoghtadaei, Talebi and Ershad (2007) presented the some recommendations for implementing open building in Iran. Due to mass housing development in Iran, open building approach include many potentials to pursue quality and flexibility, especially because of housing problems and needs.

Table 1. A Number of Related Studies

\begin{tabular}{|c|c|c|c|}
\hline Book or Article & Authors & Year & Scope \\
\hline $\begin{array}{l}\text { Reflections on the } \\
\text { history and future of } \\
\text { the open building } \\
\text { network }\end{array}$ & Kendall & $2015 a$ & $\begin{array}{l}\text { Examining the goals of open } \\
\text { building, design methods, the } \\
\text { study of open building in Asia } \\
\text { and Europe and the future of } \\
\text { the open building. }\end{array}$ \\
\hline $\begin{array}{l}\text { Developments in } \\
\text { the residential open } \\
\text { building: Analysis and } \\
\text { reflections on two } \\
\text { seminal case studies }\end{array}$ & Setien & 2015 & $\begin{array}{l}\text { The study of the main elements } \\
\text { of open building and case } \\
\text { studies. }\end{array}$ \\
\hline Diversity in Housing & Habraken & 1988 & $\begin{array}{l}\text { The introduction of open } \\
\text { building, the principles of } \\
\text { design, existing samples in } \\
\text { the world and complete } \\
\text { investigation by the founder of } \\
\text { open building. }\end{array}$ \\
\hline $\begin{array}{l}\text { The introduction } \\
\text { of open building } \\
\text { principles of the } \\
\text { residential complexes } \\
\text { for use in mass } \\
\text { construction projects } \\
\text { in Iran }\end{array}$ & $\begin{array}{l}\text { Mirmoghtadaei, } \\
\text { Talebi and Ershad }\end{array}$ & 2007 & $\begin{array}{l}\text { Introducing open building, } \\
\text { design principles, existing } \\
\text { samples in the world and ... }\end{array}$ \\
\hline
\end{tabular}

(continued on next page) 
Table 1. (continued)

\begin{tabular}{|c|c|c|c|}
\hline Book or Article & Authors & Year & Scope \\
\hline $\begin{array}{l}\text { Open building } \\
\text { concepts, } \\
\text { open building } \\
\text { implementation }\end{array}$ & Kendall & $2015 b$ & $\begin{array}{l}\text { Explaining open building } \\
\text { paradigms. }\end{array}$ \\
\hline $\begin{array}{l}\text { Open building } \\
\text { manufacturing: } \\
\text { Core concepts and } \\
\text { industrial requirements }\end{array}$ & Kazi et al. & 2007 & $\begin{array}{l}\text { In } 16 \text { chapters, they have fully } \\
\text { examined all the fields of open } \\
\text { building. }\end{array}$ \\
\hline $\begin{array}{l}\text { Built designs: Some } \\
\text { case studies in } \\
\text { residential open } \\
\text { building }\end{array}$ & Kendall & 2014 & $\begin{array}{l}\text { Examining case studies of open } \\
\text { building in a comprehensive } \\
\text { manner. }\end{array}$ \\
\hline $\begin{array}{l}\text { Notes on "Open } \\
\text { Systems" in building } \\
\text { technology }\end{array}$ & Kendall & 1987 & Open building systems. \\
\hline $\begin{array}{l}\text { Towards adaptable } \\
\text { buildings: Pre- } \\
\text { configuration and } \\
\text { re-configuration; Two } \\
\text { case studies }\end{array}$ & Gibb et al. & 2007 & $\begin{array}{l}\text { Case studies of flexible } \\
\text { buildings. }\end{array}$ \\
\hline $\begin{array}{l}\text { An open building } \\
\text { strategy for achieving } \\
\text { dwelling unit } \\
\text { autonomy in multi-unit } \\
\text { housing }\end{array}$ & Kendall & 2004 & $\begin{array}{l}\text { Methods for open building } \\
\text { application. }\end{array}$ \\
\hline $\begin{array}{l}\text { Open building: } \\
\text { An approach } \\
\text { to sustainable } \\
\text { architecture }\end{array}$ & Kendall & 1999 & $\begin{array}{l}\text { The relationship between } \\
\text { open building and sustainable } \\
\text { architecture. }\end{array}$ \\
\hline $\begin{array}{l}\text { Space puzzle in a } \\
\text { concrete box: Finding } \\
\text { design competence } \\
\text { that generates the } \\
\text { modern apartment } \\
\text { houses in Seoul }\end{array}$ & Seo & 2007 & $\begin{array}{l}\text { Modern methods for flexible } \\
\text { design. }\end{array}$ \\
\hline $\begin{array}{l}\text { Factors affecting } \\
\text { open building } \\
\text { implementation in } \\
\text { high density mass } \\
\text { construction design in } \\
\text { Hong Kong }\end{array}$ & Wong & 2010 & $\begin{array}{l}\text { Suggestions for the application } \\
\text { of open building in tall } \\
\text { buildings. }\end{array}$ \\
\hline $\begin{array}{l}\text { The efforts to develop } \\
\text { longer life housing with } \\
\text { adaptability in Japan }\end{array}$ & Minami & 2016 & $\begin{array}{l}\text { Suggestions for the application } \\
\text { of open building. }\end{array}$ \\
\hline $\begin{array}{l}\text { Report on Free Plan } \\
\text { Apartments in Moscow }\end{array}$ & $\begin{array}{l}\text { Kendall and } \\
\text { Kiseleva }\end{array}$ & 2013 & Case studies of open buildings. \\
\hline
\end{tabular}




\section{THE APPLICATION OF OPEN BUILDING IN IRAN}

The needs and necessities of the application of open building: The effect of the open building approach has not been considerable in designing the architecture of residential complexes in Iran. The application of this approach to design in Iran requires attention to the social, cultural, legal and technical characteristics of this country (Mirmoghtadaei, Talebi and Ershad, 2007). Making future changes in the building by the residents themselves and restoring the resilience of the past Iranian housing through designing residential complexes based on this approach are regarded as the most important features of designing with open building approach. The open building should achieve flexibility through technical principles and changing the interior space, which results in enhancing the need for shifting and modifying the residence.

In order to investigate the feasibility of this theory, it is necessary to examine a set of influential factors affecting the application of open building. These variables are expressed in terms of the following conceptual model (as shown in Figure 1). It should be noted that the design and construction topic which is the main topic of the present research, has been discussed in detail in this study. Other factors are briefly reviewed.

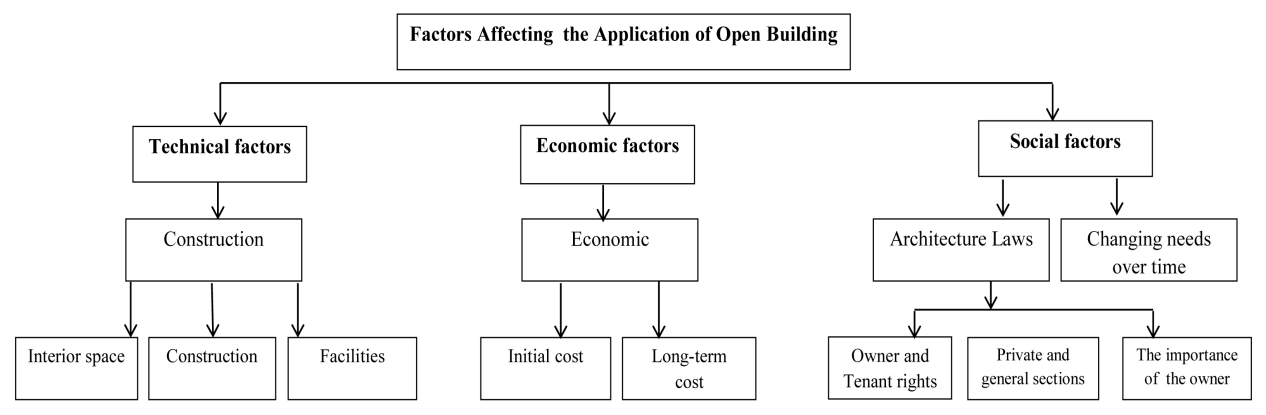

Figure 1. Influential Factors Affecting the Application of Open Building

\section{Social Factors}

Social factors are one of the most important and influential factors in this approach. These categories have different aspects as follows:

1. Rights and laws of architecture in Iran: Legal issues are among the factors which play a great impact on the application of this theory in Iran. Therefore, those laws which are relevant to making changes in residential units by current and future residents should be considered. For this purpose, public and private sectors of the apartment should be identified and reviewed. After reviewing the laws, it was evident that in some cases, there would be legal problems for using open building. Thus, the suggestions should be addressed and implemented inevitably in the area outside these cases (Mirmoghtadaei, Talebi and Ershad, 2007). Table 2 indicates a number of important issues in this area.

2. The changing needs of the family over time: Changing the pattern of life and the structure of families lead to a change in people's need for residential 
spaces. Housing and residence always follow the economic, social, cultural and climatic conditions of each region. Thus, the yesterday's house of a family is no longer suitable for tomorrow. The change in the basic family from the time of the formation to the end of the life of the couples is regarded as one of the factors which should be considered during the feasibility study of using open building. In general, it is possible to estimate the changing spatial needs of family members, which should be considered during the design process (Mirmoghtadaei, Talebi and Ershad, 2007).

Table 2. Legal Restrictions in the Application of Open Building in Iran

\begin{tabular}{ll}
\hline Limitations of Making Plan in Iran & Explanations \\
\hline The owner's and tenant's rights & $\begin{array}{l}\text { According to the Clause } 493 \text { of the Civil Rights, the } \\
\text { tenant cannot change the design of his residential } \\
\text { home without the consent of the landlord. }\end{array}$ \\
Common wall of the apartment & $\begin{array}{l}\text { The flexibility of the design should be related to the } \\
\text { internal area and cannot include the common } \\
\text { walls of the apartment. }\end{array}$ \\
Building facade & $\begin{array}{l}\text { The wall of the building facade is a part of the } \\
\text { common parts and its changing requires a majority } \\
\text { agreement of the owners. }\end{array}$ \\
\hline
\end{tabular}

Source: Mirmoghtadaei, Talebi and Ershad (2007) and Taqilou (2005)

\section{Economic Factors}

The reduction of potential costs is regarded as one of the main advantages of open building. In order to assess the economic value of open building projects, the following factors should be considered:

1. Initial cost: The initial cost of the building depends on its flexibility degree. The greater capacity of the plan for creating diversity leads to more costs. However, the capability of the plan to meet the diverse needs justifies an increase in the cost of construction. Such a building should be more durable and be able to meet the residential needs of several generations. Similarly, a building with a smaller diversity capacity would be simpler and less costly (Mirmoghtadaei, Talebi and Ershad, 2007).

2. Long-term cost: Open building may increase the initial costs to some extent based on the flexibility level, but will have considerable benefits over the long term. The residing families in this building can change the internal division of the residential space with respect to the changing needs of their own over the time and at different stages of their growth and expansion. Furthermore, since the electrical and mechanical installations of the building cross from certain areas, changing the layout of the internal separator walls becomes less expensive and takes less time, compared to conventional buildings (Mirmoghtadaei, Talebi and Ershad, 2007).

\section{Technical Factors (Design and Construction)}

Technical factors, as one of the major issues in the open building include the structural framework, facilities and internal separators. The open building approach 
is implemented with these parts in the building. The support consists of structures such as building structural elements and façade and the related facilities while the infill is concerned with the changeable items such as portable elements and interior partitions. Their details and implementation are very effective in applying this approach.

\section{OBJECTIVE AND METHOD}

The present study aimed to investigate the feasibility of using open building approach in the housing of the study area. For this purpose, the technical factors affecting open building were examined as the main variable of the study. Technical factors were studied based on construction and implementation, as well as design factors. The main research questions are as follows:

1. To what extent, is it possible to use the open building approach with respect to materials and methods of construction in the area under study?

2. To what extent, is it possible to use open building according to the existing design?

The descriptive method was used in this study. Initially, library method and the study of documents and articles were used to recognise the theory of open building. Then, the factors affecting the application of this approach were studied and summarised in a descriptive manner in Iran. It was necessary to find out the current status of existing residential buildings in the study area (Gonbad-e Kavoos city), due to technical and designing factors. Therefore, a number of residential buildings with a popular type in the region were randomly selected and their plans were reviewed and analysed. Forty buildings, including four-storeyed urban apartments built on a pilot and one to three residential units on each floor. In the next stage, the results were obtained in technical scope by performing a half-structured interview with 20 architects and construction engineers in the region. Table 3 presents the questions discussed in the interview.

Table 3. Interview Questions

\begin{tabular}{ll}
\hline Questions & \\
\hline Structure & $\begin{array}{l}\text { What structure is the most commonly used structure in residential } \\
\text { buildings in the region? } \\
\text { What new methods are used in the building structures? }\end{array}$ \\
Internal space & $\begin{array}{l}\text { Are prefabricated products and partitions used in the interior space? } \\
\text { How much prefabricated products are used in the interior space and } \\
\text { which products are used more? }\end{array}$ \\
Facilities & $\begin{array}{l}\text { What type of facility is used in residential buildings? } \\
\text { Which new methods are applied in residential buildings? }\end{array}$ \\
\hline
\end{tabular}




\section{FINDINGS AND RESULTS}

\section{Findings of the Interviews (Construction Area)}

According to the socio-economic report of Golestan province in 2011 , the most construction systems used in this province were skeletal systems with metal or concrete skeleton. Based on the field study, it was observed that the most kind of materials were concrete materials and using clay blocks for walls and ceilings of the block joist with polystyrene sheets were common in these areas. Further, the stone materials, brick and clay compositions, as well as the shotcrete and cement are the most used materials in the facade materials. In recent years, new systems and materials such as three-dimensional panel walls have been widely used. Thus, in the region, the needed background for the use of modern methods such as the machinery, manpower, access to materials and the like is desirable (naturally at a higher cost) similar to that of the many other urban areas of the country. According to the study conducted in the Modern Building Technologies in the field of open units such as separators, a wide variety of separators is usable and suitable for construction (Eram and Mirsaeedie, 2016; Building, Housing and Road Research Center, 2009). Table 4 illustrates all kinds of non-load bearing wall systems approved by the Ministry of Road and Urban Development. These systems were provided for many companies in Iran and are available in most parts of the country.

The following results were obtained based on the interviews conducted on the construction and implementation in the three areas:

1. Structure: Based on the results of the interviews and observations, the concrete and metal skeleton structures are used abundantly, although the concrete skeleton structure such as post, beam and cast is more widely used in residential usage in the region.

2. Interior space: Prefabricated productions market and its use in the field of interior separators in the region are not very active and these systems are used less in the design and implementation. Gypsum panels and other prefabricated production separators are available on the market, but rarely used and mostly used in false ceilings.

3. Facilities: In the study area, the use of vertical ducts is common and necessary. Some contractors use large-size dimension ducts which are able to travel within. It is noteworthy that using false ceilings for the passage of facilities pipes is also common and is used in many construction projects of false ceilings as a horizontal area for the distribution of ducts, pipes and other elements. Thus, there is no limitation in this field according to the applied procedures in the facility. 
Table 4. Types of Non-Load Bearing Walls Approved in Iran

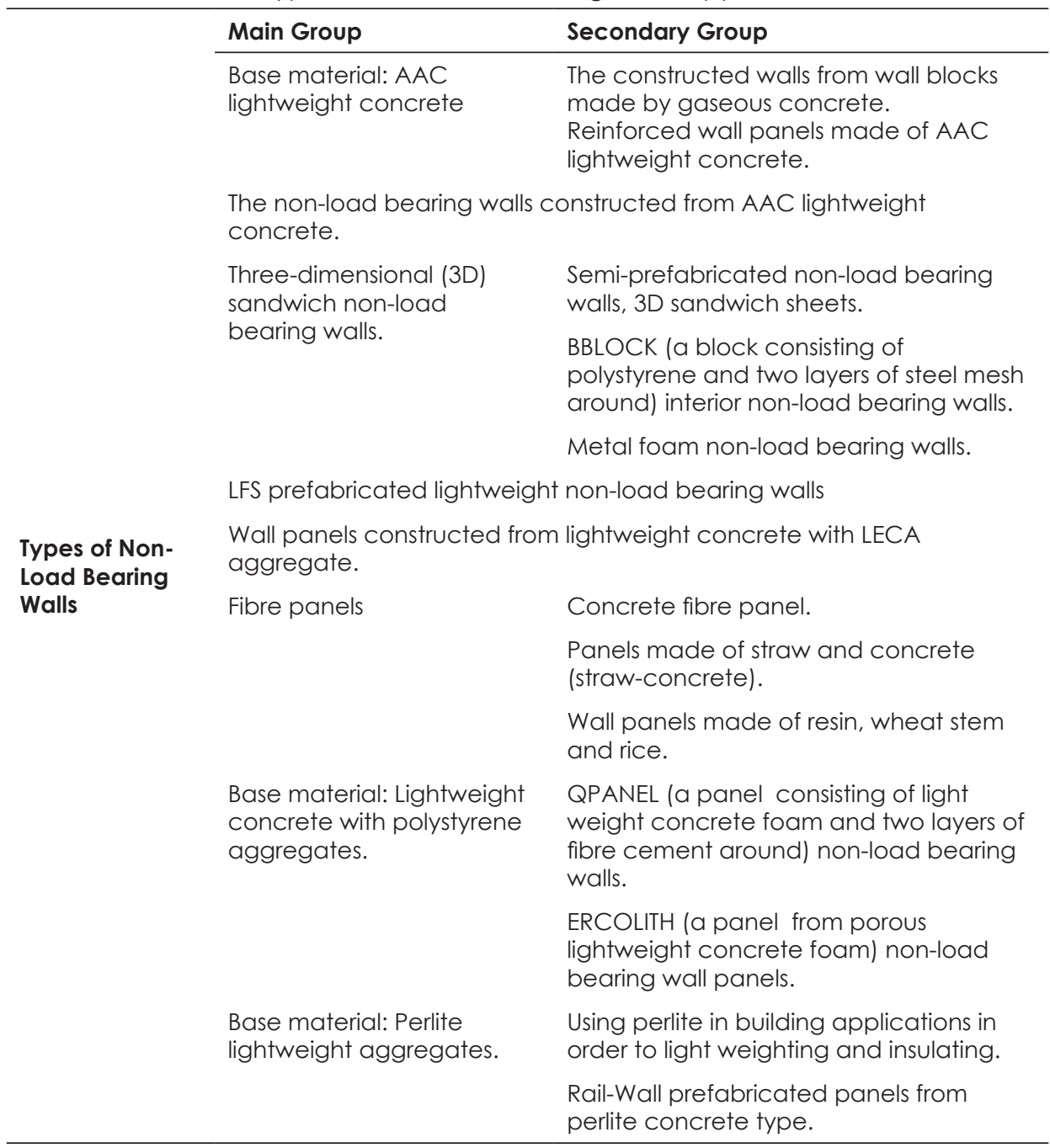

Note: AAC - Autoclaved Aerated Concrete block; LECA - Light Expanded Clay Aggregate blocks.

\section{RESULTS AND RECOMMENDATIONS IN CONSTRUCTION AREA}

1. Structure: In the area of structures, after checking the approved and licensed structural systems and the adaptation of the characteristics of open building with different structures, it was observed that there is a little structural constraint in the area of open building. However, many of the new structures have a limited use in the area, but the dominant structure is based on the adaptation, economic power and availability of a concrete structure which does not constrain the open building. To the way of adapting the structure to the design 
is important which is presented in the design section.

2. Facilities: The separation of facilities from other parts of the building is regarded as one of the major achievements of the open building. Thus, the repair and replacement of pipes will be easily feasible, in addition to the possibility of change and flexibility of the design. In popular Iranian buildings, the pipes are buried on the building floor and walls and since their life is less than the life of the building, they usually need to be replaced several times during the useful life of the building. In particular, in populated residential complexes, it is necessary to adopt specific policies for the deployment of facilities systems (Mirmoghtadaei, Talebi and Ershad, 2007). Recently, accessible vertical and horizontal channels are utilised for mechanical and electrical installations, by which the use open building is provided through increasing their use.

3. Walls and internal separators: The interior space of the building is regarded as the most important factor in open building, which should be made of prefabricated elements and elements that can be modified. In addition the variability should be provided easily and at an affordable cost for the residents. The products which require wet materials, making the work harder for residents, but gypsum panels and dry walls and movable separators are more suitable because of less complexity in construction. In general, the internal separators which are constructed through a dry construction can be used to replace the walls of the building. Table 5 demonstrates the types of walls, along with the type of their proposed materials.

Table 5. The Proposed Materials of Walls Based on the Obtained Results

\begin{tabular}{ll}
\hline Type of Building Wall & Proposed Materials \\
\hline Interior separator wall & $\begin{array}{l}\text { Dry construction, prefabricated movable separators and } \\
\text { gypsum panels. } \\
\text { Fixed building walls }\end{array}$ \\
$\begin{array}{l}\text { Common materials (bricks, types of blocks), types of } \\
\text { prefabricated panels complying with the requirements. } \\
\text { The separating wall of } \\
\text { units }\end{array}$ & $\begin{array}{l}\text { Common materials (bricks, types of blocks), types of } \\
\text { prefabricated panels complying with the requirements. }\end{array}$ \\
\hline
\end{tabular}

A slight limitation is available in the area of fixed building (structural framework and facilities) in order to promote the open building in the region. However, with respect to open units (separators, etc.); it is required to promote the use of prefabricated products such as separators and its types. This can be encouraged by the government and related institutions as part of a program to support the expansion of industrialisation of the building. Further, the development of the application of these systems provides a suitable working environment for manufacturers and operators of these systems, which can promote the building industry. 


\section{FINDINGS OF THE SAMPLE STUDY (DESIGN AREA)}

In 2007, a study was conducted on the degree of individuals' satisfaction from their home plans and their willingness to interfere in the design. The research indicated the need of residents for changes in parallel with time and the reasons for dissatisfaction with the considered space (Mirmoghtadaei, Talebi and Ershad, 2007). Based on the results, the residents tended to change spaces such as living room and dining room, kitchen and bedroom. The most important reasons for dissatisfaction with the kitchen design were its small size. Changing the kitchen mainly involves opening the wall and removing the door. Further, as higher number of rooms in the residential unit leads to more satisfaction for residents. The possibility of increasing the number of rooms, as well as integrating or separating the rooms, are among other cases which residents have demanded for more satisfaction. Furthermore, the possibility of enlarging the living and dining space was highly considered (Mirmoghtadaei, Talebi and Ershad, 2007). The possibility of integrating or separating the residential unit was regarded as another important item, which can be appropriate for the user (family of the resident) as well as the builders and sellers. The family can separate or integrate the house based on the need and over the time. As a result, the builders and vendors can also segment or integrate the building by spending less time and less cost, based on the housing market and the demand for large or small units. Any factor such as parking supply should be predicted in this regard. On the other hand, the flexibility and diversity of plans can create a variety of plans and units in a building which effectively prevents the uniformity and lack of diversity of residential units, due to the repetition of the plan in the floors, which will create better conditions for both housing buyers and sellers.

It is worth noting that wet areas such as sink, bath and at least a part of the kitchen in Iran are considered as fixed building elements and it is not possible to move or change them, due to the use of facilities and other items (Mirmoghtadaei, Talebi and Ershad, 2007).

In the present study, the popular residential buildings made by private builders were taken into consideration. These buildings usually include three or four floors on the ground and each floor has one to three residential units. In addition, the areas for each unit ranges from 70-150 sq. $\mathrm{m}$. Forty residential complexes were randomly selected in the study area and their plans were modified in terms of their variability. Table 6 indicates the analysis conducted for a number of plans. By reviewing and analysing the plans, it was found that the limited patio directions, the distribution of service spaces in the plan, the inappropriate placement of public-use area and inputs and the limiting geometry of the plan were considered as the common problems in designing area. On the other hand, the possibility of increasing the living area and kitchen, the possibility of increasing and reducing the room area and the possibility of integrating the rooms were regarded as some facilities which are available in designing many units. Table 6 presents a number of the studied samples. 
Table 6. The Study and Analysis of Some Plan Samples

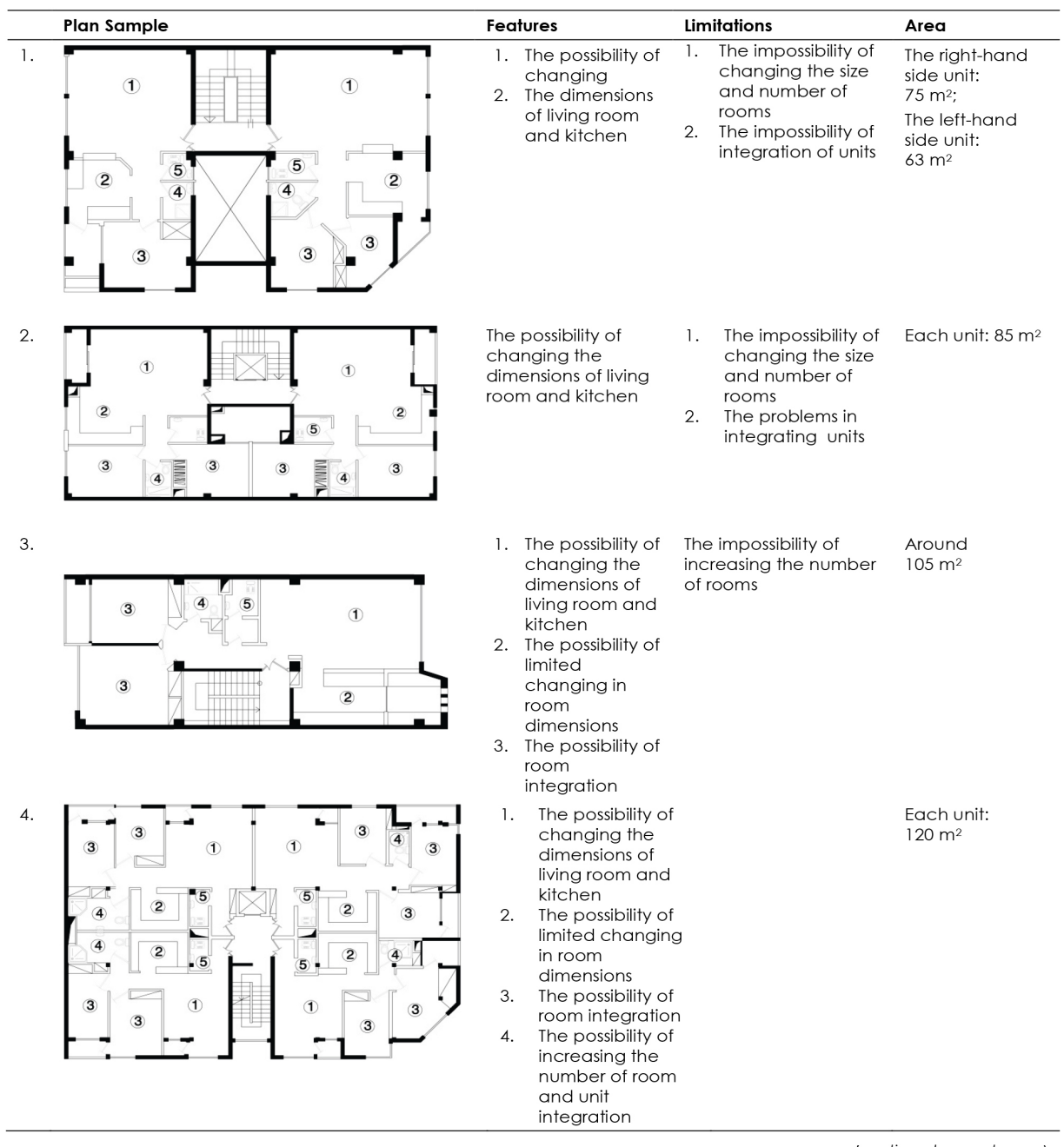

(continued on next page) 
Table 6. (continued)

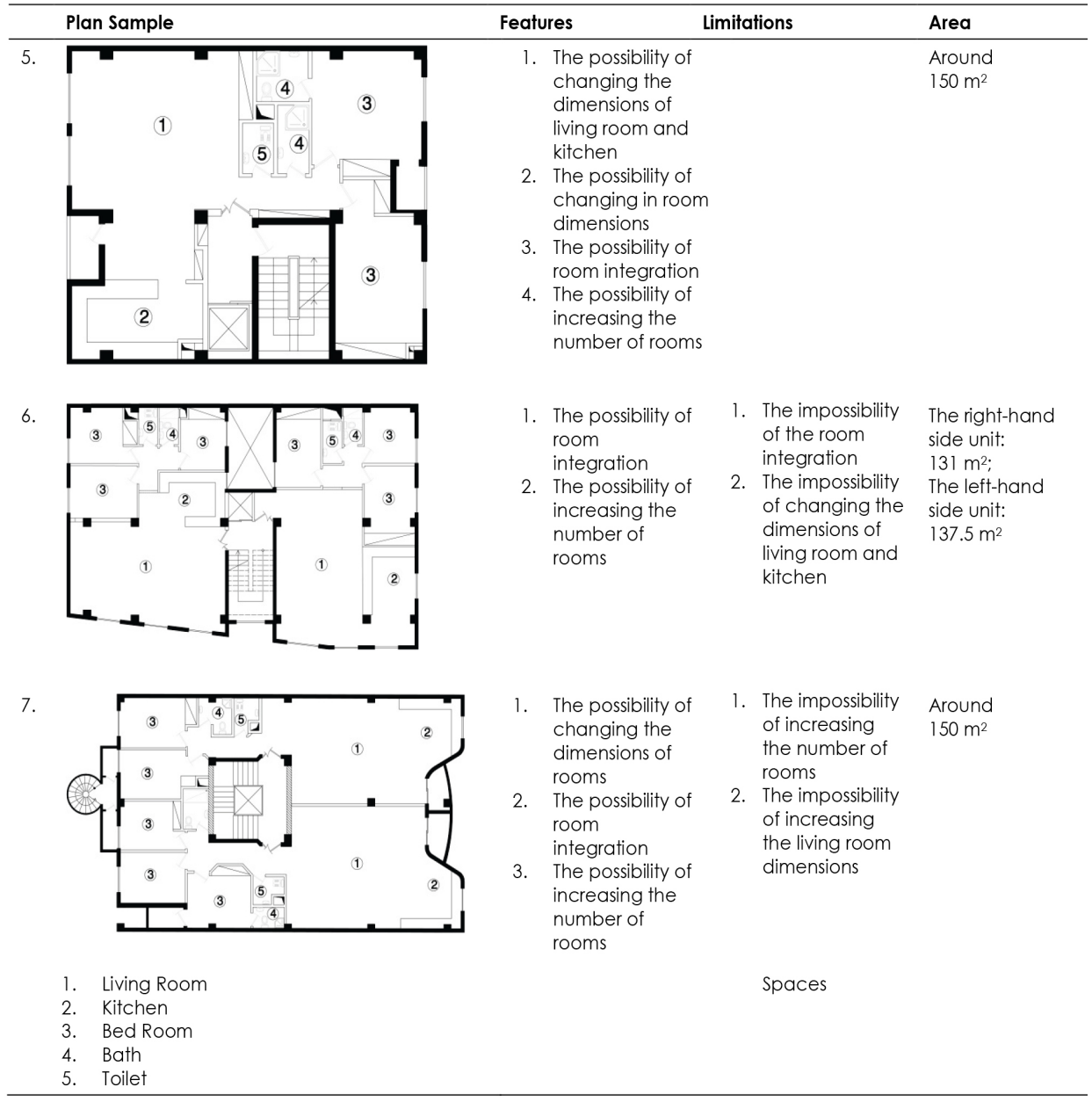

\section{RESULTS AND RECOMMENDATIONS FOR DESIGN}

After reviewing and analysing the plans, some potentials and constraints were available in the existing plans regarding the common requirements and various conditions of the design and building in the contemporary era. Accordingly, some suggestions were proposed based on the current situation by using and increasing the existing potentials and decreasing and eliminating the limitations. Table 7 indicates the suggestions related to the design process for adopting open building approach in different building sectors. 
Table 7. Design Suggestions Based on the Open Building Approach

\begin{tabular}{ll}
\hline Design Solutions for the Possibility of Open Building \\
\hline $\begin{array}{l}\text { Optimal location of } \\
\text { fixed building (supports) }\end{array}$ & $\begin{array}{l}\text { The integration of fixed building segments such as staircase and } \\
\text { services and part of the kitchen. } \\
\text { The integration of services in one range. } \\
\text { The suitable location of public-use area and inputs for providing } \\
\text { more features. } \\
\text { The suitable location of ducts and the establishment of duct } \\
\text { among the two units boundary. } \\
\text { Kitchen designing in two fixed and open parts. } \\
\text { The establishment of fixed building in non-patio directions. } \\
\text { The proximity of living room with one of the rooms. } \\
\text { The proximity of most rooms with each other. } \\
\text { The proximity of living room with the open section of kitchen. } \\
\begin{array}{l}\text { The increase of patio fronts (with suitable fill and empty or using } \\
\text { the patio). }\end{array} \\
\text { The increase of casement numbers in the external shell. } \\
\text { The placement of shear walls at the adjacent edges and the } \\
\text { staircase and in non-patio sections. } \\
\text { Regular piling with large openings. } \\
\text { Coordination of the structural framework with architectural } \\
\text { spaces. }\end{array}$ \\
\hline
\end{tabular}

\section{CONCLUSION AND DISCUSSION}

It seems that a large part of the approaches behind open building can be implemented in Iran, due to the characteristics and the proper design of the plan and taking the structures and facilities into consideration. During recent years, the construction industry has changed from providing public and mass housing to private construction by the related developers. To this aim, flexibility should be considered for designing these buildings although adapting to a variety of occupants is regarded as a forgotten area.

In construction area, a little limitation is available for the application of open building approach in terms of structures and facilities as supports in the study area, because of using the concrete skeleton structures in a widespread manner, which necessitates the use of vertical channels, risers and ducts to pass the elements of the facility and the extensive use of false ceilings in the area construction although it seems different for infills.

In design area, flexible design and the application of prefabricated separators play an influential role in designing and modifying the interior area. Given the fact that wide varieties of these partitions are currently available in the Iranian market and are easily accessible and implemented, it seems that the application of these 
elements can be very beneficial for architects and designers to achieve open building approach.

In the area of designing with open building approach, flexibility can be considered as an important and appropriate feature of housing, which is even beneficial for builders and homeowners, as well as the residents. Thus, the following recommendations are suggested:

1. Architects and designers should focus more on the building with more flexible direction from the advent of the design and pave the way for more capabilities in the process of designing, by considering open building principles, controlling and adapting the conditions and facilities related to the structures and implementing appropriate elements in the construction phase for infill units.

2. Planners and the related institutes can play a significant role in scaffolding this approach and enhancing the motivation for manufacturers and consumers of the prefabricated panels as a part of a plan to improve industrialisation.

Table 7 presents some suggestions for implementing open building approach during the process of design and construction in Iran.

In order to promote and implement open building in Iran, further studies should be conducted on the socio-economic factors as the most important factors. The investigation of barriers and legal challenges and the role of ownership in the application of open building, in addition to studying and providing a scenario for Iranian households needs over time and the like can provide the groundwork for using this approach.

\section{REFERENCES}

Building, Housing and Road Research Center (2009). New Construction Technologies [in Persian]. Tehran: Ministry of Roads and Urban Development. Available at: https://www.bhrc.ac.ir/ [Accessed on 16 July 2016].

Eram, T. and Mirsaeedie, L. (2016). Selection of optimal building system by using the analytical hierarchy process, a case study: Residential project in Gonbad-eKavoos. Paper presented at the 3rd International Conference on Research in Science and Technology. Berlin, Germany, July.

Gibb, A., Austin, S., Dainty, A., Davison, N. and Pasquire, C. (2007). Towards adaptable buildings: Pre-configuration and re-configuration; Two case studies. In $M$. Sharp (ed.), Manubuild: Proceedings of the 1st International Conference, the Transformation of the Industry; Open Building Manufacturing. London: The Construction Industry Research and Information Association (CIRIA).

Golestan Governorship (2011). Socioeconomic Report of Golestan Province [in Persian]. Golestan, Iran: Golestan Governorship. Available at https:// golestanp.ir/ [Accessed on 8 September 2017].

Habraken, J. (1978). Diversity in Housing. Translated by G. Faridian and N. Yazdkhasti. Tehran: Iranian Student Book Agency.

Kazi, A., Hannus, M., Boudjabeur, S. and Malone, A. (2007). Open Building Manufacturing Core Concepts and Industrial Requirements. Espoo, Finland: Manubuild with VTT-Technical Research Centre of Finland. 
Kendall, S. (2015a). Reflections on the History and Future of the Open Building Network, CIB W104 (1996-2015). Delft, The Netherlands: International Council for Research and Innovation in Building and Construction (CIB). . (2015b). Open Building Concepts, Open Building Implementation, CIB W104. Delft, The Netherlands: CIB.

. (2014). Case Studies of Residential Open Building. Continuing Project of the Building Futures Institute (BFI). Muncie, Indiana: College of Architecture and Planning, Ball State University.

- (2004). An open building strategy for achieving dwelling unit autonomy in multi-unit housing. Housing and Society, 31 (1): 89-99. https://doi.org/10.1080/ 08882746.2004 .11430500 .

- (1999). Open building: An approach to sustainable architecture. Journal of Urban Technology, 6(3): 1-16.

- (1987). Notes on "open systems" in building technology. Building and Environment, 22(2): 93-100. https://doi.org/10.1016/0360-1323(87)90029-1.

Kendall, S. and Kiseleva, N. (2013). Report on free plan apartments in Moscow. Available at: http://drstephenkendall.com/open-building-studies-reportsand-lectures/ [Accessed on 5 September 2017].

Minami, K. (2016). The efforts to develop longer life housing with adaptability in Japan. Energy Procedia, 96: 662-673. https://doi.org/10.1016/j.egypro.2016.09.124.

Mirmoghtadaei, M., Talebi, Z. and Ershad, L. (2007). Introduction to the Principles of Open Building of Residential Complexes for Use in Mass Construction Projects [in Persian]. Tehran: Building and Housing Research Center Publication.

Seo, K.W. (2007). Space puzzle in a concrete box: Finding design competence that generates the modern apartment houses in Seoul. Environment and Planning B: Planning and Design, 34: 1071-1084. https://doi.org/10.1068/b32134.

Setien, I.N. (2015). Development in the residential open building: Analysis and reflections on two seminal case studies. Perkins+Will Research Journal, 7(1): 19-35.

Taqilou, Z. (2005). Legal Issues of Apartments [in Persian]. 2nd Ed. Tehran: Partoe Khorshid Publication.

Wong, J.F. (2010). Factors affecting open building implementation in high density mass construction design in Hong Kong. Habitat International, 34(2): 174-182. https://doi.org/10.1016/j.habitatint.2009.09.001. 